\title{
GIVING RED RICE (ORIZA NIVARA) TO CHANGE GLUCOSE LEVELS IN DIABETES MELLITUS PATIENTS IN KENDARI CITY
}

\author{
Laode Ardiansyah $^{1 *}$, Nawawi $^{2}$ \\ ${ }^{12}$ Universitas Mandala Waluya, in Kendari Southeast Sulawesi Province, Indonesia \\ Corresponding Author: Laode Ardiansyah \\ Email : -
}

\section{Abstract}

Background:Diabetes mellitus (DM) is a phenomenon which the body cannot produce insulin supply which is indicated by increasing blood glucose levels. Red Rice (Oriza nivara) contains flavonoid compounds which have antidiabetic abilities. It can reduce blood glucose by increasing insulin secretion and preventing insulin resistance. This study aims to determine the effect of giving brown rice (Oriza nivara) to change blood glucose levels in people with diabetes mellitus in Kendari City.

Methods: This research method was carried out with a quasi-experimental design with pre-post test design for 1 week with primary and secondary data collection techniques. The respondents were determined by proportional random sampling. Respondents in this study were 33 people with DM.

Result:The results of the study on checking blood glucose levels before and after giving brown rice (oriza nivara) within 1 week obtained $\mathrm{P}$ value $=0.000<$ alpha 0.05 .

Conclusion: there is a significant effect of giving brown rice (oriza nivara) on changes in blood glucose level in diabetes mellitus people in Kendari City.

Key words: Brown Rice, Blood Glucose, Levels, Diabetes Mellitus.

\section{INTRODUCTION}

Indonesian Journal Of Health Sciences Research and Development 
One of health problems faced by the government and society in Indonesia is diabetes mellitus. One type of disease experienced by the community is diabetes mellitus. DM is a disease caused by the body not being able to produce insulin (a hormone that produces blood glucose) or an insufficient supply of insulin. This can lead to an increase in blood glucose(1).

Based on IDF data (2015) the number of DM sufferers was 415 million people in 2015 and is expected to increase to 642 million in 2040. In Southeast Sulawesi, according to BPS data (2016), DM is a disease that ranks 4 th out of 10 highest diseases, with a total of 7,357 patients. The area in Southeast Sulawesi with the highest DM cases is Kendari City. Kendari City has DM data for the last 3 years, namely in 2016 the cases reached 161 cases, in 2017 there was an increase of 223 cases and in 2018 there were 190 patients(2).

Diabetes mellitus is closely related to blood glucose levels, so it is necessary to check blood glucose at any time. Control of blood glucose levels in DM sufferers is related to excess food intake which results in an increase in blood sugar levels (3). Increased blood glucose (hyperglycemia) can cause damage to insulin-producing $\beta$ cells of the pancreas. Free radicals such as supraoxide, hydrogen peroxide, nitric oxide and hydroxyl that damage the $\beta$ cells of the pancreas so that the amount of insulin produced by the body will decrease. This causes glucose unable to enter the cells and accumulate in the blood, causing hyperglycemia. In this case, antioxidants are needed to fight free radicals.

Brown rice (Oriza nivara) contains carbohydrates, fats, protein, fiber and minerals and also contains flavonoid compounds which have the ability to be antidiabetic which lowers blood glucose by increasing insulin secretion and preventing insulin resistance (4). The purpose of this study was to determine the effect of giving red rice (Oriza nivara) to changes in blood glucose levels in diabetes mellitus patients in Kendari City.

\section{METHOD}

This type of research is a Quasi Experiment Design with a pre-post test design. The pre-post test design is a research conducted by giving a pretest before being given intervention, after which intervention is given, then a posttest is carried out (5).

This research will be carried out in Kendari City with a population of people with DM disease in Kendari City based on data from the Kendari City Health Office in 2018 totaling 190 people. To determine the number of samples in this study was to use the Slovin formula in order to obtain a total sample of 66 people with diabetes mellitus.

The results of the calculation using this formula are the number of samples given brown rice (Oriza nivara), there are 33 samples of patients with intervention given for 1 week with blood glucose measurements before being given and after being given intervention in DM patients, with information on GDS test on venous plasma $\leq$ $100 \mathrm{mg} / \mathrm{dL}$ means normal or decreased GDS, if $\geq 200 \mathrm{mg} / \mathrm{dL}$ means that the GDS is not normal or there is no decrease, while the capillary GDS measurement $\leq 90 \mathrm{mg} / \mathrm{dL}$ means that the GDS is normal or decreases, if $\geq 200 \mathrm{mg} / \mathrm{dL}$ means that the GDS is not normal or does not occur(6).

\section{RESULT}

Table 1 shows that the most age group is at the age of 60-69 years there are 10 patients $(30.30 \%)$, then in the group and age $>70$ years there are 9 people $(30.30 \%)$, aged 50 - 59 years as many as 8 sufferers $(24.24 \%)$ while the age group 40-49 years were 6 patients $(18.18 \%)$.

Table 2 shows that the lowest gender of the respondents is male 27 people $(40.91 \%)$ and the highest is female, amounting to 39 people (59.09\%).

Table 3 shows that the measurement results of respondents with diabetes mellitus in Kendari City before and after giving 
brown rice (oriza nivara) for one week with a frequency of 3 times a day with portions adjusted for their calorie needs. There were 19 people with diabetes mellitus who experienced changes in normal blood glucose levels, and those who did not experience normal changes but entered after being given red rice intervention (Oriza nivara) were 14 people.

Table 4 shows that the data normality test uses the Shapiro-Wilk statistical test with the interpretation that if the $\mathrm{P}$ Value> 0.05 then the data is normally distributed, but if the $\mathrm{P}$ Value $<0.05$ then the data is not normally distributed. But if there is one test before giving intervention and after the intervention is not normally distributed, it is assumed that the test results are not normally distributed. Based on the results of the normality test of giving brown rice (oriza nivara) before and after the data was not normally distributed. Therefore, the normality test used is the non-parametric statistical test Wilcoxon Signed Ranks test.

After the Wilcoxon Signed Ranks test statistical test was carried out with a determined significant level of $\mathrm{P}$ Value $<0.05$ on the examination of blood glucose levels before and after giving brown rice (oriza nivara) within 1 week obtained $\mathrm{P}$ Value $=0.000$ from these data $\mathrm{P}$ Value $<0.05$ (Table 5). This shows that there is an effect of giving brown rice (oriza nivara) on changes in blood glucose in people with diabetes mellitus in Kendari City.

Table 1

Distribution of Respondents by Age Group

\begin{tabular}{llll}
\hline No. & Age Group (years) & n & \% \\
\hline 1. & $40-49$ & 6 & 18.18 \\
2. & $50-59$ & 8 & 24.24 \\
3. & $60-69$ & 10 & 30.30 \\
4. & $\geq 70$ & 9 & 27.27 \\
\hline amount & 33 & 100 \\
\hline
\end{tabular}

Primary data, 2020

Table 2

Distribution of Respondents by Gender

\begin{tabular}{llll}
\hline No. & Gender & $\mathbf{n}$ & \% \\
\hline 1. & Male & 14 & 42.42 \\
2. & Women & 19 & 57.57 \\
\hline amount & 33 & 100 \\
\hline
\end{tabular}

Primary data, 2020 
Ardiansyah, L\& Nawawi

DOI: 10.36566/ijhsrd/Vol3.Iss1/52

https://ijhsrd.com/index.php/ijhsrd

e- ISSN: $2715-4718$

Table 3

Measurement of Blood Glucose Levels Before and After Giving Brown Rice (Oriza nivara)

\begin{tabular}{|c|c|c|c|c|}
\hline \multirow[b]{2}{*}{ No. } & \multicolumn{2}{|c|}{$\begin{array}{c}\text { Changes in Blood } \\
\text { Glucose }\end{array}$} & \multirow{2}{*}{$\begin{array}{c}\text { Differe } \\
\text { nce } \\
\text { Value }\end{array}$} & \multirow{2}{*}{$\begin{array}{l}\text { Description Normal } \\
\leq 200 \mathrm{mg} / \mathrm{dL}\end{array}$} \\
\hline & $\begin{array}{c}\text { Pre } \\
\text { Test } \\
\text { (mg / } \\
\text { dL) }\end{array}$ & $\begin{array}{c}\text { Post Test (1 } \\
\text { Week) } \\
(\mathrm{mg} / \mathrm{dl})\end{array}$ & & \\
\hline 1 & 485 & 527 & -42 & Abnormal \\
\hline 2 & 561 & 328 & 233 & Abnormal \\
\hline 3 & 350 & 268 & 82 & Abnormal \\
\hline 4 & 220 & 109 & 111 & Normal \\
\hline 5 & 201 & 319 & -118 & Abnormal \\
\hline 6 & 215 & 137 & 78 & Normal \\
\hline 7 & 228 & 149 & 79 & Normal \\
\hline 8 & 298 & 334 & -36 & Abnormal \\
\hline 9 & 500 & 328 & 172 & Abnormal \\
\hline 10 & 450 & 220 & 230 & Abnormal \\
\hline 11 & 550 & 245 & 305 & Abnormal \\
\hline 12 & 448 & 248 & 200 & Abnormal \\
\hline 13 & 240 & 185 & 55 & Normal \\
\hline 14 & 550 & 245 & 305 & Abnormal \\
\hline 15 & 374 & 184 & 190 & Normal \\
\hline 16 & 450 & 129 & 321 & Normal \\
\hline 17 & 260 & 138 & 122 & Normal \\
\hline 18 & 285 & 195 & 90 & Normal \\
\hline 19 & 276 & 152 & 124 & Normal \\
\hline 20 & 347 & 198 & 149 & Normal \\
\hline 21 & 545 & 238 & 307 & Abnormal \\
\hline 22 & 336 & 185 & 151 & Normal \\
\hline 23 & 274 & 128 & 146 & Normal \\
\hline 24 & 380 & 192 & 188 & Normal \\
\hline 25 & 420 & 200 & 220 & Normal \\
\hline 26 & 229 & 138 & 91 & Normal \\
\hline 27 & 580 & 258 & 322 & Abnormal \\
\hline 28 & 420 & 209 & 211 & Abnormal \\
\hline 29 & 480 & 198 & 282 & Normal \\
\hline 30 & 385 & 182 & 203 & Normal \\
\hline 31 & 450 & 216 & 234 & Abnormal \\
\hline 32 & 480 & 200 & 280 & Normal \\
\hline 33 & 300 & 165 & 135 & Normal \\
\hline amount & 12567 & 7147 & 5420 & \\
\hline
\end{tabular}

Primary data, 2020 
Table 4

Data Normality Test Before and After giving Brown Rice (Oriza nivara)

to Changes in Blood Glucose Levels in Patients with Diabetes Mellitus

Examination of

Blood Glucose

P-Value

a

Conclusion

Levels

\begin{tabular}{lllc}
\hline Pre & 0,000 & 0.78 & Abnormal \\
Post & 0,000 & 0.00 & Normal \\
\hline
\end{tabular}

Primary data, 2020

Table 5

The Wilcoxon Signed Ranks test of the Provision of Brown Rice (Oriza nivara)

\begin{tabular}{lccccc}
\hline $\begin{array}{c}\text { Giving of Red } \\
\text { Nas (Oriza } \\
\text { nivara) }\end{array}$ & Median & Maximum & Maximum & $\begin{array}{c}\text { Statistic } \\
\text { test }\end{array}$ & p value \\
\hline $\begin{array}{l}\text { Measurement of } \\
\text { Blood Glucose }\end{array}$ & 380,000 & 201 & 580 & 0.00 & 0,000 \\
$\begin{array}{l}\text { Levels Pre-Post } \\
\text { Test (1 Week) }\end{array}$ & & & & \\
Primary data, 2020 & & & & & \\
\hline
\end{tabular}

\section{DISCUSSION}

The Effect of Giving Brown Rice (Oriza nivara) to Changes in Blood Glucose Levels in Diabetes Mellitus Patients in the Working Area of Kendari City

Measurement of blood glucose levels in people with diabetes mellitus, before and after the intervention of brown rice (oriza nivara) with a time span of 1 week frequency 3 times a day with portions adjusted for calorie needs. Thus, 19 patients with blood glucose in the normal range $\leq 200 \mathrm{mg} / \mathrm{dl}$ had diabetes mellitus, while 14 patients who did not experience changes in blood glucose levels were still above> $200 \mathrm{mg} / \mathrm{dl}$. The results of the data normality test obtained that the data were not normally distributed so that it was continued with the non-parametric statistical test Wilcoxon Signed Ranks test with a significant level determined was $\mathrm{P}$ Value $<0.05$ on checking blood glucose levels before and after giving brown rice (oriza nivara) in time 1 week obtained $\mathrm{P}$ Value $=0.000$ from the data $\mathrm{P}$ value $<0.05$.
The results of this study are in line with(7) research, regarding the effectiveness of giving rice diets in reducing blood sugar levels in diabetes mellitus sufferers at Puskesmas Pandemawu Pamekasan, out of 76 diabetes mellitus patients before and after giving brown rice intervention for 1 week, brown rice results are effective. against decreased blood glucose levels in diabetes mellitus patients. On research(8), of the total research sample amounted to 36 samples consisting of the treatment group being given brown rice for 6 days at breakfast and dinner, while the control group did not receive any intervention. The results showed that the initial and final cholesterol levels of the treatment group were $235.69 \mathrm{mg} / \mathrm{dL}$ and $198.56 \mathrm{mg} / \mathrm{dL}$, while the initial and final cholesterol levels of the control group were $235.72 \mathrm{mg} / \mathrm{dL}$ and $256.50 \mathrm{mg} / \mathrm{dL}$. In this study, giving brown rice was effective in reducing total cholesterol levels in patients with type 2 diabetes mellitus. 
The process of changing blood glucose by giving brown rice (oriza nivara) is due to the high fiber content in brown rice. The benefits of fiber in brown rice can increase the viscosity of the lumen in the intestine so that it can decrease the efficiency of carbohydrate absorption and insulin response. By decreasing the insulin response, the work of the pancreas will be lighter in producing insulin. Brown rice (oriza nivara) can also reduce lipid levels in serum so that it can reduce glucose levels in the blood. In addition, brown rice contains the mineral selenium and anthocyanin pigments (red) which function as antioxidants and act as an inhibitor of various degenerative diseases including diabetes mellitus (9).

Brown rice also contains Gama Amino Butiric Acid (GABA) which can stimulate pancreatic $\beta$ cells to produce more insulin(10). If insulin production increases, it will suppress the Sensitive Lipase Hormone (HSL) which plays a role in lipolysis so that blood glucose levels will decrease. In addition, brown rice contains essential fatty acids that can reduce blood glucose levels by clearing plasma from chylomicron lipoproteins and reducing the production of triglycerides and $\beta$ apoloproteins in the liver(11). As for diabetes mellitus sufferers after being given brown rice (oriza nivara) but there is no change in the normal range due to the presence of patients consuming foods that can trigger an increase in blood glucose, drinking coffee, smoking which can cause an increase in blood glucose in people with diabetes mellitus.

External factors that cause no change in blood glucose levels after the intervention of brown rice (oriza nivara) is that patients have various characteristics of age and gender. A person aged 35 years and over is more likely to have postprandial hyperglycemia than someone less than 35 years of age. Likewise for gender, women are more likely to suffer from diabetes mellitus due to the influence of the hormone estrogen which can directly increase insulin and strengthen glucose stimulation to insulin secretion so that pancreatic $\beta$ cells experience fatigue so that it can trigger diabetes mellitus (12). Women are also more at risk of experiencing postrandial hyperglycemia than men (13).

\section{CONCLUSION}

Examination of blood glucose levels before and after giving brown rice (oriza nivara) within 1 week obtained $\mathrm{P}$ value $=$ 0.000 from $P$ value $<0.05$. The conclusion is that there is an effect of giving brown rice (oriza nivara) on changes in blood glucose in diabetes mellitus sufferers in Kendari City

\section{REFERENCES}

1. Ministry of Health R. Main results of RISKESDAS 2018. Online) http: // wwwMinistry of Health go id / resources / download / latest-info / material_rakorpop_2018 / Results\% 20Riskesdas. 2018; 202018.

2. BP statistics. Human Development Index 2016. Kendari Southeast Sulawesi: Central Bureau of Statistics. 2017.

3. Amir SM, Wungouw H, Pangemanan D. Current blood glucose levels in type 2 diabetes mellitus patients at the Shoulder Health Center, Manado city. eBiomedics. 2015; 3 (1).

4. DAHLIA S. The Effect of White Rice, Red and Black Rice Dekok on the Effects of Hyperglycemia in Swiss Webster 2019 Male White Mice.

5. Mackey A, Gass SM. Second language research: Methodology and design: Routledge; 2015.

6. Ratu G, Badji A. Profile of Urinary Tract Stones Analysis in Clinical Pathology Laboratory. Indonesian Journal of Clinical Pathology and Medical Laboratory. 2018; 12 (3): 114-7.

7. Kuszairi K. The Effectiveness of Giving Brown Rice Diet in Lowering Blood Sugar Levels in Diabetes Mellitus Patients at Pademawu Puskesmas 
Pamekasan. Journal of Islamic Medicine. 2017; 1 (2): 97-107.

8. Pradini WU, Marchianti ACN, Riyanti R. The effectiveness of brown rice to reduce total cholesterol levels in Type 2 DM patients (The Effectiveness of Red Rice to Decrease Total Cholesterol in Type 2 DM Patients). 2017.

9. Salamah IR. Diversification of Cookies with Addition of Red Rice Flour (Oryza nivara) Against Anthocyanin Levels and Acceptability: STIKES PKU Muhammadiyah Surakarta; 2017.

10. Pradini WU, Marchianti ACN, Riyanti R. The effect of red rice to decrease total cholesterol in type $2 \mathrm{dm}$ patients. AMS Journal. 2017; 3 (1): 7-12.

11. Diass WC, Estiasih T. Effect of Dioscoreaceae Family Tuber Bioactive Compounds on Blood Lipid Profile Conditions: A Literature Review [IN PRESS APRIL 2015]. Journal of Food and Agroindustry. 2014; 3 (2): 424-30.

12. McLennan $R$, Schumacher LJ, Morrison JA, Teddy JM, Ridenour DA, Box AC, et al. Neural crest migration is driven by a few trailblazer cells with a unique molecular signature narrowly confined to the invasive front. Development. 2015; 142 (11): 2014-25.

13. Rensiansi L, Iwaningsih S. Effect of Consumption of Ir-36 Rice and Brown Rice on Blood Sugar Level Profiles of Type 2 Diabetes Patients in Public Health Centers, Pasar Rebo District, East Jakarta. ARGIPA (Nutrition and Food Archives). 2016; 1 (1): 41-50. 